\title{
KAJIAN SOSIAL EKONOMI DAN TINGKAT KESEJAHTERAAN RUMAH TANGGA PETANI KELAPA SAWIT DI KABUPATEN TULANG BAWANG
}

\author{
(Social Economic Study and The Welfare Level of Oil Palm Farmer Households \\ in Tulang Bawang Regency)
}

Rahma Lalita, R Hanung Ismono, Fembriarti Erry Prasmatiwi

\begin{abstract}
Jurusan Agribisnis, Fakultas Pertanian, Universitas Lampung, Jl. Prof. Dr. Soemantri Brojonegoro No.1
Bandar Lampung 35141, Telp. 082279298011, e-mail: rahmalalita@ gmail.com
\end{abstract}

\begin{abstract}
This study aims to determine the social, economic and welfare level of oil palm farmer households in Tulang Bawang Regency. The study was conducted in August 2017. The research sample was 54 farmers who are divided into two categories, namely 46 farmers of narrow land and 8 farmers of wide land. The data is analyzed by qualitative description. The level of well-being is measured by socio-metric indicators. The results of the study showed that the average farmer respondents in the study area either of narrow land or wide land had good social categories conditions. Income earned by farmers from oil palm farming of narrow land was Rp29,941,900 / year with a contribution of $83.87 \%$ and of labor was $3.91 \%$ from the available 329 men working day/year. Farmers of the wide area had earned Rp86,165,100/year from oil palm farming with a contribution of $94.65 \%$ and of labor was $19.82 \%$ of the 329 men working day/year. The level of welfare showed that both of narrow land and large land were in the category of not poor.
\end{abstract}

Key words: economic conditions, oil palm, social conditions, welfare

\section{PENDAHULUAN}

Provinsi Lampung memiliki potensi di bidang kelapa sawit. Potensi ini dapat dilihat dari jumlah luas dan produksi kelapa sawit yang tinggi di Provinsi Lampung. Pembangunan perkebunan kelapa sawit di Provinsi Lampung di harapkan mampu meningkatkan nilai tambah, membuka dan memperluas lapangan kerja, meningkatkan pendapatan, mengentaskan kemiskinan sehingga meningkatkan devisa yang dapat mendukung pembangunan dan pertumbuhan ekonomi di Provinsi Lampung. Setiap kabupaten di Provinsi Lampung memiliki potensi dan kemampuan berbeda mengenai budidaya kelapa sawit.

Kabupaten Tulang Bawang memiliki peluang yang cukup tinggi untuk pengembangan perkebunan kelapa sawit. Menurut BPS (Badan Pusat Statistika Provinsi Lampung 2015), Kabupaten Tulang Bawang menempati posisi kedua sebagai salah satu daerah sentra perkebunan kelapa sawit setelah Kabupaten Mesuji dengan total luas areal 36.672 ha dan total produksi sebesar 95.548 ton. Fakta tersebut menunjukan peluang besar bagi Kabupaten Tulang Bawang dalam rangka mengembangkan agribisnis kelapa sawit. Petani kelapa sawit yang ada di Kabupaten Tulang Bawang umumnya adalah penduduk transmigran yang merupakan program pemerintah yang berpindah pada sekitar tahun 1994. Tiap-tiap kepala keluarga diberikan tanah seluas dua hektar dengan pembagian 0,25 ha untuk pekarangan, 0,75 ha untuk usahatani kelapa sawit yang bermitra dengan perusahaan dan sisanya seluas satu hektar lahan petani digunakan untuk menanam tanaman lain, yang umumnya pada saat itu adalah tanaman palawija. Namun, semakin lama dan semakin banyaknya pengelolaan usahatani tanaman kelapa sawit dan adanya seranggan gajah dan babi hutan menyebabkan lahan menjadi rusak, sehingga mengakibatkan terganggunya produksi tanaman palawija dan terjadinya peralihan tanaman ke kelapa sawit. Tahun 2000 program PIR sudah tidak ada lagi, sehingga mulai tahun 2000, petani yang menanam tanaman kelapa sawit adalah petani swadaya.

Jumlah petani swadaya dari tahun ke tahun terus bertambah dan pada akhirnya menyebabkan berkebun kelapa sawit menjadi salah satu mata pencaharian utama masyarakat di lokasi penelitian hingga saat ini. Di Kabupaten Tulang Bawang, masih banyak petani kelapa sawit yang mengatakan bahwa keuntungan perkebunan kelapa sawit yang tinggi hanya dirasakan oleh petani kelapa sawit yang memiliki lahan luas ( $>5 \mathrm{ha}$ ) dan bagi petani kelapa sawit yang memiliki lahan sempit (1-2 ha), berkebun kelapa sawit tidak memberikan dampak yang begitu berarti terhadap 
perekonomian keluarga petani (hanya cukup untuk kebutuhan pokok saja).

Prospek perkebunan kelapa sawit di masa depan dinilai sangat baik, dimana salah satu sub sektor perkebunan ini diharapkan akan mampu menciptakan lapangan pekerjaan di pedesaan. Melihat betapa potensialnya perkebunan kelapa sawit tersebut sehingga tidak heran bahwa budidaya tanaman kelapa sawit dinilai dapat memberikan peningkatan pendapatan rumah tangga petani, yang mampu meningkatkan pula kondisi sosial dan ekonomi petani tersebut.

Penelitian ini bertujuan untuk, pertama mengkaji kondisi sosial rumah tangga petani kelapa sawit di Kabupaten Tulang Bawang. Kedua, mengkaji kondisi ekonomi rumah tangga petani kelapa sawit di Kabupaten Tulang Bawang. Ketiga, mengkaji tingkat kesejahteraan rumah tangga petani kelapa sawit di Kabupaten Tulang Bawang.

\section{METODE PENELITIAN}

Metode penelitian yang digunakan pada penelitian ini adalah survei. Penelitian ini dilakukan di Kabupaten Tulang Bawang. Penentuan lokasi penelitian dilakukan secara sengaja (purposive) dengan pertimbangan Kabupaten Tulang Bawang memiliki jumlah produksi dan petani kelapa sawit tertinggi kedua di Provinsi Lampung. Lokasi yang menjadi sampel penelitian ini adalah Kecamatan Penawar Tama (Desa Bogatama, Sidodadi, Sidoarjo, dan Wiratama) dan Kecamatan Gedung Aji Baru (Desa Merkatitama). Pengumpulan data dilakukan pada bulan Agustus 2017. Sampel penelitian berjumlah 54 petani dimana dalam perhitungan dibagi menjadi dua, yaitu 46 petani dengan luas lahan $<4$ ha (lahan sempit) dan 8 petani dengan luas lahan $>4$ ha (lahan luas).

Metode analisis yang digunakan untuk mengetahui kondisis sosial rumah tangga petani kelapa sawit di Kabupaten Tulang Bawang yakni analisis deskriptif kualitatif. Pengukuran kondisi sosial dilakukan menggunakan empat indikator dengan parameter pengukuran tertentu. Keempat indikator yang digunakan dalam pengukuran kondisi sosial yakni indikator pendidikan, perumahaan dan lingkungan, taraf dan pola konsumsi, dan gaya hidup. Kondisi sosial diukur secara keseluruhan dengan metode Range Score yang kemudian dibedakan menjadi dua katagori yaitu baik dan kurang baik dengan rumus sebagai berikut (Badan Pusat Statistika 2014) :
$\mathrm{RS}=\frac{\mathrm{SkT}-\mathrm{SkR}}{\mathrm{JKl}}$

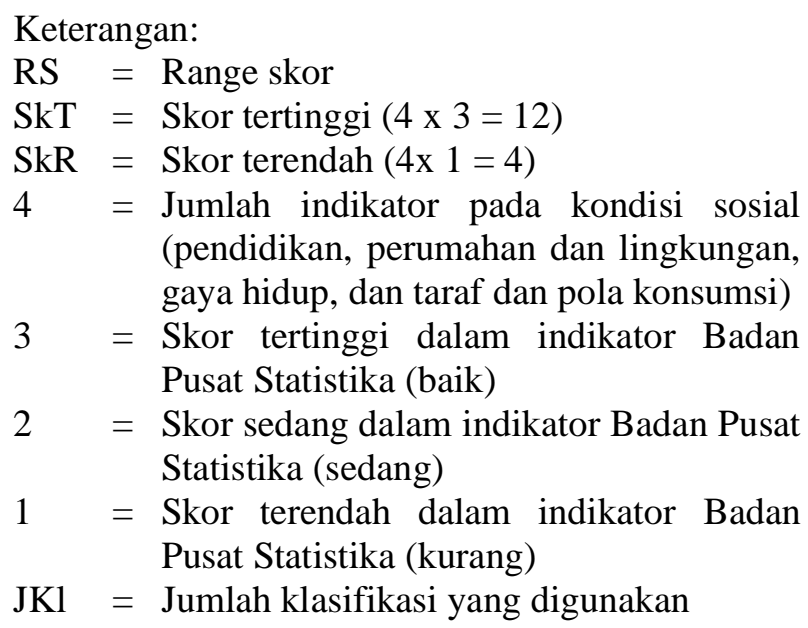

Hasil perhitungan berdasarkan rumus tersebut diperoleh range skor (RS) sama dengan tujuh, sehingga kondisi sosial rumah tangga petani kelapa sawit adalah sebagai berikut:

(1) Jika skor antara 4-8 berarti rumah tangga petani memiliki kondisi sosial yang kurang baik.

(2) Jika skor antara 9-12 berarti rumah tangga petani memiliki kondisi sosial yang baik.

Kondisi ekonomi pada penelitian terdiri dari empat indikator yaitu pendapatan usahatani kelapa sawit, pendapatan rumah tangga petani kelapa sawit, kontribusi pendapatan petani kelapa sawit terhdap pendapatan rumah tangga, dan curahan tenaga kerja. Pendapatan usahatani kelapa sawit diperoleh dengan menghitung selisish penerimaan dengan semua biaya produksi, dirumuskan sebagai berikut (Soekartawi 2002) :

$\pi=\mathrm{YP}_{\mathrm{y}^{-}} \sum \mathrm{X}_{\mathrm{i}} \mathrm{P}_{\mathrm{xi}}$

Keterangan:

$\Pi \quad=$ Pendapatan usahatani kelapa sawit

$\mathrm{Y} \quad=$ Produksi kelapa sawit

Py = Harga produksi kelapa sawit

$\mathrm{Xi} \quad=$ Faktor produksi, $\mathrm{i}=1,2,3,4 \ldots \ldots ., \mathrm{n}$

$\mathrm{Pxi}=$ Harga faktor produksi

Pendapatan rumah tangga petani diperoleh dengan cara menjumlahkan pendapatan keluarga yang berasal dari on farm, off farm, dan non farm. Menurut rumus Hastuti dan Rahim (2008), pendapatan rumah tangga petani adalah :

$\mathrm{P}_{\mathrm{rt}}=\mathrm{P}_{\text {usahatani }}+\mathrm{P}_{\text {off farm }}+\mathrm{P}_{\text {non farm }}$ 
Keterangan :

Prt $=$ Pendapatan rumah tangga petani per tahun

$\mathrm{P}_{\text {usahatani }}=$ Pendapatan dari usahatani kelapa sawit + non sawit

$\mathrm{P}_{\text {off farm }}=$ Pendapatan dari pertanian tetapi diluar budidaya usahatani

$\mathrm{P}_{\text {non farm }}=$ Pendapatan dari luar pertanian

Kontribusi setiap sumber pendapatan petani dapat mencerminkan komponen penyusun struktur pendapatan rumah tangga petani dan dapat dihitung dengan rumus sebagai berikut :

$\mathrm{Kpu}=\frac{\text { Pendapatan usahatani }}{\text { Pendapatan total rumah tangga }} \times 100 \%$

Keterangan:

$\mathrm{Kpu}=$ Kontribusi pendapatan usahatani

Kapasitas TKDK (Tenaga Kerja Dalam Keluarga) dilihat dari jumlah maksimum tenaga kerja yang dapat dipekerjakan oleh petani responden dalam 1 bulan. Menurut Karmini dan Aisyah (2008), Kapasitas TKDK merupakan jumlah tenaga kerja dalam rumah tangga petani responden setiap bulan. Kapasitas TKDK tiap bulannya dihitung dengan menggunakan rumus sebagai berikut:

$\mathrm{K}=(\mathrm{JH} \times \mathrm{TKp} \times 1)+(\mathrm{JH} \times \mathrm{TKw} \times 0,8)$

Keterangan:

$\mathrm{K}=\operatorname{Kapasitas}(\mathrm{HOK} / \mathrm{bulan} / \mathrm{mt})$

$\mathrm{JH}=$ Jumlah hari kerja tiap bulan (hari/bulan)

$\mathrm{TKp}=$ Jumlah tenaga kerja pria dalam keluarga (orang)

$\mathrm{TKw}=$ Jumlah tenaga kerja wanita dalam keluarga (orang)

Analisis yang digunakan untuk mengkaji tingkat kesejahteraan rumah tangga petani kalapa sawit adalah menggunakan indikator sosio-metrik. Foundation for International Community Assistance mengklasifikasikan indikator sosiometrik keluarga sejahtera berdasarkan delapan komponen kesejahteraan yaitu ketahanan pangan, pendidikan, pelayanan kesehatan, perumahan, modal sosial, pemberdayaan, buta huruf, dan kerawanan dalam keluarga tersebut (Mufikhati dalam Syahputra 2010).

Pengklasifikasian indikator dilakukan dengan pemberian skor berdasarkan kondisi aktual yang dialami oleh keluarga (skor dari 1 sampai dengan 4). Selanjutnya, skor dari masing - masing aspek tersebut dijumlahkan dan diperoleh klasifikasi dengan kisaran $8-15$ : tidak miskin, $16-23$ : miskin, $24-32$ : sangat miskin.

\section{HASIL DAN PEMBAHASAN}

Responden penelitian terdiri dari 54 petani dimana dalam perhitungan dibagi menjadi dua, yaitu 46 petani dengan luas lahan $<4$ ha (lahan sempit) dengan rata-rata luas lahan petani 1,76 ha dan 8 petani dengan luas $>4$ ha (lahan luas) dengan ratarata luas lahan petani 8,19 ha. Usia petani responden baik pada petani lahan sempit maupun pada lahan luas memiliki rata-rata usia pada interval 49-55 tahun atau usia produktif. Rata-rata pendidikan petani responden yaitu SMA dengan rata-rata pengalaman usahatani kelapa sawit yaitu selama 10-15 tahun.

\section{Analisis Kondisi Sosial Rumah Tangga Petani Kelapa Sawit di Kabupaten Tulang Bawang}

Hasil penelitian yang diperoleh menunjukan bahwa, petani responden yang memiliki lahan sempit memiliki dua indikator yang memperoleh katagori baik, yaitu indikator pendidikan dan indikator perumahan dan lingkungan, sedangkan dua indikator lainnya memperoleh katagori cukup baik, yaitu indikator gaya hidup dan indikator taraf dan pola konsumsi. Petani responden yang memiliki lahan luas, ketiga indikator yaitu pendidikan, perumahan \& lingkungan, dan taraf \& pola konsumsi berada pada katagori baik sedangkan indikator gaya hidup berada pada katagori cukup baik.

Akumulasi dari ke empat indikator kondisi sosial yang telah diperoleh tersebut dapat kita ketahui apakah rata-rata petani responden dalam katagori kondisi sosial yang baik atau kurang baik dengan kriteria total skor akhir yaitu baik (9-12) dan kurang baik (4-8). Jumlah rata-rata nilai pada petani responden yang memiliki lahan sempit maupun petani yang memiliki lahan luas masingmasing yaitu sebesar 10 dan 12 atau kondisi sosial petani responden berada pada katagori baik. Kondisi sosial dapat dilihat pada Tabel 1. 
Tabel 1. Hasil skor masing-masing indikator kajian sosial petani kelapa sawit di Kabupaten Tulang Bawang, 2017

\begin{tabular}{|c|c|c|c|c|c|c|c|c|c|c|c|c|}
\hline \multirow{3}{*}{ Indikator } & \multirow{2}{*}{\multicolumn{3}{|c|}{$\begin{array}{c}<4 \text { ha } \\
\text { (Lahan sempit) } \\
\text { Skor } \\
\end{array}$}} & \multirow{3}{*}{$\begin{array}{l}\text { Total } \\
\text { skor }\end{array}$} & \multirow{3}{*}{$\begin{array}{l}\text { Skor } \\
\text { rata- } \\
\text { rata }\end{array}$} & \multirow{3}{*}{ Kategori } & \multirow{2}{*}{\multicolumn{3}{|c|}{$\begin{array}{c}>4 \text { ha } \\
\text { (Lahan luas) } \\
\text { Skor } \\
\end{array}$}} & \multirow{3}{*}{$\begin{array}{l}\text { Total } \\
\text { skor }\end{array}$} & \multirow{3}{*}{$\begin{array}{c}\text { Skor } \\
\text { rata- } \\
\text { rata }\end{array}$} & \multirow{3}{*}{ Kategori } \\
\hline & & & & & & & & & & & & \\
\hline & 1 & 2 & 3 & & & & 1 & 2 & 3 & & & \\
\hline Pendidikan & 9 & 113 & 154 & 697 & 15,15 & Baik & 3 & 1 & 44 & 137 & 17,13 & Baik \\
\hline $\begin{array}{l}\text { Perumahan dan } \\
\text { Lingkungan }\end{array}$ & 2 & 62 & 478 & 1.560 & 33,91 & Baik & 0 & 8 & 88 & 280 & 35,00 & Baik \\
\hline Gaya hidup & 150 & 148 & 32 & 542 & 11,78 & Cukup baik & 12 & 18 & 26 & 126 & 15,75 & Cukup baik \\
\hline Taraf dan Pola Konsumsi & 62 & 63 & 59 & 365 & 7,93 & Cukup baik & 0 & 5 & 27 & 91 & 11,38 & Baik \\
\hline Jumlah & 223 & 386 & 723 & 3.164 & 68,78 & 10 (Baik) & 15 & 32 & 185 & 634 & 79,25 & 11 (Baik) \\
\hline
\end{tabular}

Keterangan :

Indikator 1 : Pendidikan, baik (15-18), cukup baik (11-14), dan kurang baik (6-10)

Indikator 2 : Perumahan dan Lingkungan, baik (29-36), cukup baik (21-28), dan kurang baik (12-20)

Indikator 3 : Gaya hidup, baik (18-21), cukup baik (12-17), dan kurang baik (7-11)

Indikator 4 : Taraf dan Pola Konsumsi, baik (10-12), cukup baik (7-9), dan kurang baik (4-6)

Kategori : Baik (3), cukup baik (2), kurang baik (1)

\section{Analisis Kondisi Ekonomi Rumah Tangga Petani Kelapa Sawit di Kabupaten Tulang Bawang}

Analisis pendapatan usahatani diperoleh dari penerimaan usahatani dikurangin dengan biayabiaya usahatani. Penerimaan merupakan hasil kali jumlah produksi dengan harga yang diterima petani. Biaya-biaya usahatani terdiri dari biaya tunai dan biaya diperhitungkan. Petani yang dengan lahan sempit memiliki rata-rata luas lahan 1,76 ha sedangkan petani dengan lahan luas memiliki rata-rata luas lahan 8,19 ha. Penerimaan yang diperoleh petani dari hasil usahatani kelapa sawit di daerah penelitian pada petani responden yang memiliki lahan sempit yaitu sebesar Rp18.643.900/ha/th, sedangkan untuk petani responden yang memiliki lahan luas memiliki penerimaan yaitu sebesar Rp19.809.000/ha/th. Pengeluaran dari biaya-biaya tunai (pupuk, obatobatan, tenaga kerja luar keluarga, dan PBB) pada petani responden yang memiliki lahan sempit yaitu sebesar Rp1.079.400/ha/th, sedangkan untuk petani responden yang memiliki lahan luas memiliki ratarata biaya tunai yaitu sebesar $\mathrm{Rp} 2.705 .100 / \mathrm{ha} / \mathrm{th}$.

Perhitungan dari biaya-biaya diperhitungkan (sewa lahan, penyusutan alat, dan tenaga kerja dalam keluarga) pada petani yang memiliki lahan sempit yaitu sebesar Rp9.106.703/ha/th sedangkan pada petani yang meiliki lahan luas memiliki rata-rata biaya diperhitungkan sebesar Rp9.176.200/ha/th. Dengan demikian dapat diketahui bahwa total biaya atau penjumlah dari biaya tunai dan diperhitungkan pada petani yang memiliki lahan sempit sebesar Rp10.186.100/ha/th, sedangkan pada petani yang memiliki lahan luas memiliki rata-rata biaya total sebesar Rp11.881.254,07 /ha/th.

Pendapatan rumah tangga terdiri dari pendapatan on farm, pendapatan off farm, dan pendapatan non farm. Pada pendapatan on farm, selain kelapa sawit, petani juga mendapatkan pendapatan dari usahatani lain yaitu usahatani karet dan ternak. Pada petani yang memiliki lahan sempit pendapatan usahatani karet yaitu sebesar Rp3.104.300/th dan pendapatan ternak yaitu sebesar Rp156.500/th. Pada petani yang memiliki lahan luas tidak ada pendapatan on farm selain kelapa sawit atau $100 \%$ sumber pendapatan dari usahatani yaitu berasal dari kelapa sawit. Pendapatan yang diperoleh petani dari pendapatan off farm, pada petani yang memiliki lahan sempit yaitu sebagai buruh tani, dengan pendapatan sebesar Rp772.200/th dan pada petani yang memiliki lahan luas tidak ada pendapatan off farm.

Pendapatan yang diperoleh petani dari pendapatan non farm, pada petani yang memiliki lahan sempit yaitu berasal dari buruh non pertanian (Rp589.100/th), pedagang (Rp717.400/th), lapak (Rp1.043.500/th), dan PNS/Honorer/Pg.Swasta (Rp1.434.800/th). Pada petani yang memiliki lahan luas, pendapatan non farm berasal dari pedagang (Rp375.000/th) dan PNS/Honorer/ Pg.Swasta (Rp4.500.000/th). Dengan demikian dapat diketahui bahwa total pendapatan rumah tangga petani kelapa sawit yang memiliki lahan sempit adalah sebesar Rp35.698.900/th dan petani yang memiliki lahan luas yaitu sebesar Rp91.040.000/th. 
Tabel 2. Penerimaan, biaya, dan pendapatan petani responden usahatani kelapa sawit per hektar di Kabupaten Tulang Bawang, 2017

\begin{tabular}{|c|c|c|c|c|c|c|}
\hline \multirow{3}{*}{ Uraian } & \multicolumn{6}{|c|}{ Usahatani Kelapa sawit per ha } \\
\hline & \multicolumn{3}{|c|}{$<4$ ha (Lahan sempit) } & \multicolumn{3}{|c|}{$>4$ ha (Lahan luas) } \\
\hline & Jumlah & Harga (Rp) & Nilai (Rp) & Jumlah & Harga $(\mathrm{Rp})$ & Nilai (Rp) \\
\hline Total Penerimaan 1 tahun & & & $18.643 .941,91$ & & & $19.918 .700,20$ \\
\hline \multicolumn{7}{|l|}{ Biaya Produksi } \\
\hline \multicolumn{7}{|l|}{ Biaya Tunai } \\
\hline Pupuk Urea & 84,582 & $2.162,50$ & $182.909,12$ & 133,07 & 2037,50 & $271.120,91$ \\
\hline Pupuk Phonska & 77,96 & $3.251,52$ & $253.504,30$ & 88,33 & 3166,67 & $279.722,22$ \\
\hline Pupuk KCL & 11,33 & $5.558,33$ & $62.979,80$ & 30,00 & 5566,67 & $167.000,00$ \\
\hline Pupuk Kandang & 174,95 & 487,857 & $85.348,70$ & 250,97 & 488,00 & $122.474,44$ \\
\hline Obat-obatan & 1,95 & & 99643,94 & 1,63 & & $87.913,87$ \\
\hline TK Luar Keluarga & 4,23 & & 366011,79 & 22,06 & & $1.747 .118,06$ \\
\hline PBB & & & 28978,26 & & & $29.750,00$ \\
\hline Total Biaya Tunai & & & $1.079 .375,91$ & & & 2.705.099,51 \\
\hline \multicolumn{7}{|l|}{ Biaya diperhitungkan } \\
\hline Sewa Lahan & & & $8.000 .000,00$ & & & $8.000 .000,00$ \\
\hline TK dalam Keluarga & 7,31 & & $561.978,28$ & 7,96 & & 631429,76 \\
\hline Penyusutan Alat & & & $620.686,82$ & & & $544.724,80$ \\
\hline Total Biaya diperhitungkan & & & $9.182 .665,11$ & & & $9.175 .847,08$ \\
\hline Total Biaya & & & $10.262 .041,01$ & & & $11.880 .946,59$ \\
\hline \multicolumn{7}{|l|}{ Pendapatan } \\
\hline I. Pendapatan Atas Biaya Tunai & & & $17.564 .566,01$ & & & $17.213 .600,69$ \\
\hline II. Pendapatan Atas Biaya Total & & & $8.381 .900,90$ & & & $8.037 .753,61$ \\
\hline $\mathrm{R} / \mathrm{C}$ atas biaya tunai & & & 17,27 & & & 7,36 \\
\hline $\mathrm{R} / \mathrm{C}$ atas biaya total & & & 1,82 & & & 1,68 \\
\hline
\end{tabular}

Tabel 3. Kontribusi pendapatan usahatani kelapa sawit terhadap pendapatan rumah tangga petani kelapa sawit di Kabupaten Tulang Tulang, 2017

\begin{tabular}{|c|c|c|c|c|}
\hline \multirow[b]{2}{*}{ Jenis Kegiatan Petani } & \multicolumn{2}{|c|}{$<4$ ha (Lahan sempit) } & \multicolumn{2}{|c|}{$>4$ ha (Lahan Luas) } \\
\hline & $\begin{array}{c}\text { Pendapatan per tahun } \\
(\mathrm{Rp})\end{array}$ & Kontribusi (\%) & $\begin{array}{c}\text { Pendapatan per tahun } \\
(\mathrm{Rp})\end{array}$ & Kontribusi (\%) \\
\hline \multicolumn{5}{|l|}{ Lahan sempit } \\
\hline Usahatani & 31.141 .900 & & 86.165 .100 & \\
\hline${ }^{\wedge}$ Kelapa sawit & 29.941 .900 & 83,87 & 86.165 .100 & 94,65 \\
\hline$\wedge^{\wedge}$ Karet & 1.043 .500 & 2,92 & 0 & 0,00 \\
\hline${ }^{\wedge}$ Ternak & 156.500 & 0,44 & 0 & 0,00 \\
\hline Off Farm & 772.200 & & 0 & \\
\hline${ }^{\wedge}$ Buruh petani & 772.200 & 2,16 & 0 & 0,00 \\
\hline Non Farm & 7.306 .500 & & 4.875 .000 & \\
\hline Buruh non pertanian & 589.100 & 1,65 & 0 & 0,00 \\
\hline Pedagang & 717.400 & 2,01 & 375000 & 0,41 \\
\hline Lapak & 1.043 .500 & 2,92 & 0 & 0,00 \\
\hline PNS/Hnr/Pg Swst & 1.434 .800 & 4,02 & 4500000 & 4,94 \\
\hline Jumlah & 35.698 .900 & 100,00 & 91.040 .100 & 100,00 \\
\hline
\end{tabular}

Pada kontribusi pendapatan usahatani kelapa sawit terhadap pendapatan rumah tangga petani dapat diketahui bahwa petani responden yang memiliki lahan sempit, kontribusi pendapatan usahatani kelapa sawit adalah sebesar 83,87 persen terhadap pendapatan rumah tangga petani, sedangkan pada lahan luas, kontribusi pendapatan usahatani kelapa sawit adalah sebesar 94,65 persen terhadap pendapatan rumah tangga petani.

\section{Kapasitas Tenaga Kerja}

Berdasarkan perhitungan kapastias tenaga kerja dapat diketahui bahwa ketersediaan tenaga kerja pada tenaga kerja dalam keluarga (TKDK) adalah $329 \mathrm{HOK} /$ th. Penggunaan TKDK untuk usahatani kelapa sawit pada petani yang memiliki lahan sempit dengan luas lahan rata-rata 1,76 ha yaitu $12,88 \mathrm{HOK} /$ /th atau hanya sebesar 3,91 persen 
penggunaan TKDK dari jumlah kapasitas TKDK yang tersedia. Pada petani yang memiliki lahan luas penggunaan TKDK per luas lahan (8,91 ha) yaitu 65,21 HOK/th atau hanya sebesar 19,82 persen dari jumlah kapasitas TKDK yang tersedia.

Jika dilihat dari sumber tenaga kerja keluarga petani responden (TKDK), dapat diketahui bahwa masih banyak kapasitas tenaga kerja yang tersisa yang dimiliki rumah tangga petani responden. Data ini menunjukan bahwa perlunya petani responden dalam memanfaatkan tenaga kerja yang tersedia tersebut pada kegitan-kegiatan lainnya yang dapat menunjang dan meningkatkan pendapatan rumah tangga petani responden.

\section{Analisis Tingkat Kesejahteraan Rumah Tangga Petani Kelapa Sawit di Kabupaten Tulang Bawang}

Pada sosio metrik, tingkat kesejahteraan dibedakan menjadi tiga, yaitu kisaran $8-15$ : tidak miskin, 16 -23 : miskin, $24-32$ : sangat miskin. Pada Tabel 4 dapat diketahui bahwa pada petani yang memiliki lahan sempit maupun lahan luas berada pada katagori tidak miskin dengan skor rata-rata yang diperoleh pada petani yang memiliki lahan sempit yaitu sebesar 9,07 dan pada petani yang memiliki lahan luas yaitu sebesar 10,65.

Indikator ketahanan pangan dilihat berdasarkan kemampuan keluarga untuk mencukupi kebutuhan pangan dan keinginan terhadap suatu bahan tertentu. Sebanyak 89,13 persen petani responden yang memiliki lahan sempit dan 100 persen petani responden yang memiliki lahan luas mengatakan bahwa keluarga selalu mempunyai pangan dalam jumlah yang cukup dan jenis yang diinginkan. Hanya 10,87 persen petani responden yang memiliki lahan sempit yang mengatakan bahwa keluarga selalu mempunyai pangan dalam jumlah yang cukup tetapi tidak selalu jenis yang diinginkan. Indikator pendidikan responden dinilai berdasarkan kemampuan keluarga untuk mencapai tingkat tertinggi pendidikan dalam keluarganya. Sebanyak 52,17 persen petani responden yang memiliki lahan sempit dan 50 persen petani responden yang memiliki lahan luas mengatakan bahwa keluarga dapat mendukung pendidikan untuk anak sampai pendidikan tinggi dan universitas. Sisanya 47,83 persen petani responden yang memiliki lahan sempit dan 50 persen petani responden yang memiliki lahan luas mengatakan bahwa keluarga dapat mendukung pendidikan untuk anak sampai sekolah menengah atas.

Indikator pelayanan kesehatan dinilai berdasakan kemampuan keluarga dalam memperoleh mengobatan. Sebanyak 50,00 persen petani responden yang memiliki lahan sempit maupun lahan luas mengatakan bahwa keluarga selalu mampu untuk memperoleh obat-obatan dan pelayanan kesehatan yang dibutuhkan. Sisanya sebanyak 50,00 persen petani responden pada lahan sempit maupun lahan luas mengatakan bahwa keluarga biasanya mampu untuk memperoleh obat-obatan dan pelayanan kesehatan yang dibutuhkan.

Indikator peralatan rumah tangga melihat bagaimana kelengkapan peralatan rumah tangga petani responden yang terdiri dari pompa air, listrik, septictank, dan telpon (HP). Sebanyak 89,13 persen petani responden yang memiliki lahan sempit dan 100,00 persen petani responden yang memiliki lahan luas mengatakan bahwa keluarga mempunyai seluruh perlengkapan modern termasuk pompa air, listrik, septictank, dan telpon. Sisanya sebanyak 10,87 persen responden yang memiliki lahan sempit mengatakan bahwa keluarga memiliki tiga dari empat perlengkapan yang ada.

Tabel 4. Kesejahteraan petani kelapa sawit di Kabupaten Tulang Bawang, 2017

\begin{tabular}{|c|c|c|c|c|c|c|c|c|c|c|c|}
\hline \multirow[t]{2}{*}{ Indikator } & \multicolumn{4}{|c|}{ Skor } & \multirow{2}{*}{$\begin{array}{l}\text { Skor rata- } \\
\text { rata }\end{array}$} & \multicolumn{4}{|c|}{$\frac{\text { Skor }}{>4 \text { ha (Lahan luas) }}$} & \multirow{2}{*}{$\begin{array}{l}\text { Skor rata- } \\
\text { rata }\end{array}$} & \multirow[t]{2}{*}{ Katagori } \\
\hline & 1 & 2 & 3 & 4 & & 1 & 2 & 3 & 4 & & \\
\hline Ketahanan pangan & 41 & 5 & 0 & 0 & 0,94 & 8 & 0 & 0 & 0 & 1,00 & \\
\hline Pendidikan & 24 & 22 & 0 & 0 & 1,26 & 4 & 4 & 0 & 0 & 1,50 & \\
\hline Pelayanan Kesehatan & 23 & 23 & 0 & 0 & 1,22 & 4 & 4 & 0 & 0 & 1,50 & \\
\hline Peralatan Rumah Tangga & 41 & 5 & 0 & 0 & 0,94 & 8 & 0 & 0 & 0 & 1,00 & \\
\hline Modal Sosial & 20 & 24 & 2 & 0 & 1,39 & 3 & 4 & 1 & 0 & 1,75 & Idak VIskin \\
\hline Pemberdayaan & 7 & 38 & 1 & 0 & 1,59 & 2 & 5 & 1 & 0 & 1,88 & \\
\hline Kemampuan Baca Tulis & 46 & 0 & 0 & 0 & 0,85 & 8 & 0 & 0 & 0 & 1,00 & \\
\hline Kerawanan & 45 & 1 & 0 & 0 & 0,87 & 8 & 0 & 0 & 0 & 1,00 & \\
\hline Jumlah & 248 & 115 & 3 & 0 & 9,07 & 45 & 17 & 2 & 0 & 10,65 & \\
\hline
\end{tabular}


Indikator modal sosial dinilai berdasarkan frekuensi keterlibatan petani pada kegiatan yang ada dilingkungan masyarakat mereka. Sebanyak 43,48 persen petani responden yang memiliki lahan sempit dan 37,50 persen petani responden yang memiliki lahan luas mengatakan bahwa petani selalu terlibat dalam aktifitas masyarakat. Selanjutnya sebanyak 52,17 persen petani responden yang memiliki lahan sempit dan 50 persen petani responden yang memiliki lahan luas mengatakan bahwa petani terkadang tetapi tidak selalu terlibat dalam aktifitas masyarkat. Sisanya sebanyak 6,52 persen petani responden yang memiliki lahan sempit dan 12,5 persen petani responden yang memiliki lahan luas mengatakan bahwa petani jarang terlibat dalam aktifitas masyarakat.

Indikator pemberdayaan, dilihat dari persepsi petani responden terhadap perlakuan masyarakat dilingkungannya. Sebanyak 15,22 persen petani responden yang memiliki lahan sempit dan 25,00 persen petani responden yang memiliki lahan luas mengatakan bahwa petani selalu merasa dihormati. Selanjutnya sebanyak 82,61 persen petani responden yang memiliki lahan sempit dan 62,50 persen petani responden yang memiliki lahan luas mengatakan bahwa petani terkadang merasa dihormati. Sisanya sebanyak 2,70 persen petani responden yang memiliki lahan sempit dan 12,5 persen petani responden yang memiliki lahan luas mengatakan bahwa petani jarang merasa dihormati.

Indikator kemampuan baca tulis responden menunjukan bahwa seluruh petani responden pada penelitian pada lahan sempit maupun lahan luas mengatakan bahwa mereka dapat membaca, menulis, dan berhitung dasar. Indikator kerawanan dinilai berdasarkan ada tidaknya resiko kerawanan dalam keluarga. Sebanyak 97,83 persen petani responden yang memiliki lahan sempit dan sebanyak 100,00 persen petani yang memiliki lahan luas mengatakan bahwa keluarga tidak mempunyai kerawanan (balita, lansia, anggota keluarga berpenyakit kronis). Hanya terdapat 2,70 persen responden yang memiliki lahan sempit yang mengatakan bahwa petani memiliki satu dari tiga kerawanan yang ada.

\section{KESIMPULAN}

Kondisi sosial petani responden yang memiliki lahan sempit maupun lahan luas berada pada katagori baik. Kondisi ekonomi petani responden yang memiliki lahan sempit maupun lahan luas juga berada pada keadaan yang baik dimana R/C atas biaya total menunjukan nilai $\mathrm{R} / \mathrm{C}>1$ yaitu pada petani yang memiliki lahan sempit nilai $\mathrm{R} / \mathrm{C}$ sebesar 1,82 dan petani yang memiliki lahan luas nilai $\mathrm{R} / \mathrm{C}$ sebesar 1,68. Tingkat kesejahteraan petani responden menunjukan bahwa baik pada petani yang memiliki lahan sempit maupun petani yang memiliki lahan luas berada pada katagori tidak miskin.

\section{DAFTAR PUSTAKA}

Anggraeni SA, Prasmatiwi FE, dan Sitomorang S. 2018. Analisis pendapatan rumah tangga dan pemasaran kakao di Kecamatan Bulok Kabupaten Tanggamus. JIIA, 4(1)1-7. http://jurnal.fp.unila.ac.id/index.php/JIA/articl e/view/1208/1105. [23Agustus 2018].

Badan Pusat Statistik. 2014. Indikator Kesejahteraan Rakyat 2007. Badan Pusat Statistik. Jakarta.

Badan Pusat Statistik Provinsi Lampung. 2015. Luas Areal dan Produksi Perkebunan Kelapa Sawit. https://lampung.bps.go.id/ index.php/ publikasi/2. [12 November 2016].

Dedi M. 2014. Faktor-faktor sosial ekonomi yang mempengaruhi pendapatan usahtani kelapa sawit pola sawadaya di Desa Kepau Jaya Kabupaten Kampar. Jurnal RAT 3 (1). [09 Desember 2016].

Dinas Perkebunan Provinsi Lampung. 2015. Luas Areal Tanaman Perkebunan Rakyat Kabupaten Tulang Bawang Tahun 2015. Dinas Perkebunan Provinsi Lampung. Lampung.

Fauzi Y. 2002. Kelapa Sawit. Penebar Swadaya. Jakarta.

Gusti AI, Haryono D, dan Prasmatiwi FE. 2013. Analisis pendaptan dan tingkat kesejahteraan rumah tangga petani di Desa Pesawaran Indah Kecamatan Padang Cermin Kabupaten Pesawaran. JIIA,1(4):278283.http://jurnal.fp. unila.ac.id/index.php/JIA/article/view/701/6 4. [26 Agustus 2018].

Karmini S dan Aisyah. 2008. Optimalisasi lahan usahatani tomat dan mentimun dengan kendala tenaga kerja (Pendekatan Program Linier). Jurnal EPP : 2 (5) : 25-27. [27 Januari 2017]

Pasaribu MC, Prasmatiwi FE, dan Murniarti K. 2017. Anailsis kelayakan finansial usahatani kakao di Kecamatan Bulok Kabupaten Tanggamus. JIIA, 5(3)258-266. http://jurnal. fp.unila.ac.id/index.php/JIA/article/view/1638 /1 464 [23 Agustus 2018].

Sisi AA. 2016. Studi Sosial Ekonomi Petani Karet dan Kelapa Sawit Berdasarkan Penguasaan 
Lahan (Studi Kasus di Desa Wonosari, Mesuji Timur). Skripsi. Universitas Lampung. Lampung.

Soekartawi. 2002. Teori Ekonomi Produksi; Dengan Pokok Bahasan analisis Fungsi Cobb-Douglas. Raja Grafindo Persada. Jakarta.

Syahputra P. 2018. Analisis Tingkat Partisipasi, Struktur dan Distribusi Pendapatan Rumah Tangga serta Tingkat Kesejahteraan Anggota
Koperasi Serba Usaha Peternakan Motivasi Doa Ikhtiar dan Tawakal (KSUP MDIT) di Kecamatan Gisting Kabupaten Tanggamus Tesis. Universitas Lampung. Lampung.

Tetty W. 2010. Analisis sosial ekonomi usahatani kelapa sawit di Desa Suliliran Baru Kecamatan Pasir Belengkong Kabupaten Paser. Volume 27 Nomor 1, Februari 2010 Hal. 41-53. [26 Desember 2017]. 